\title{
Editorial
}

\section{Lições brasileiras na busca do Direito Universal à Saúde}

$\mathrm{O}$ processo da reforma sanitária no Brasil é inspiração para os países latinoamericanos por ser um projeto político de mudança de valor, a partir da garantia da saúde universal e da solidariedade como fatores estruturantes na fundamentação dos direitos sociais - o que deve ser traduzido na proteção e na seguridade social.

No contexto desses princípios, o Sistema Único de Saúde (SUS) deve ser concebido como uma estratégia de construção da democracia por meio da ampliação da esfera pública, da inclusão social e da redução das desigualdades .

O SUS é a institucionalização parcial dos princípios da reforma sanitária, já que a atenção e o cuidado aos quais se destina é parte do direito à saúde. Mesmo assim, a consolidação do SUS tem grande significado em se tratando de análises sobre os rumos da reforma sanitária. É preciso distinguir e ressaltar que o SUS referido deve ser universal, assim como oferecer integralidade, qualidade e humanização como base de sua organização e funcionamento.

$\mathrm{O}$ atual financiamento público da saúde não é condizente com o projeto universalista da Constituição Federal. Este projeto requer, entre tantas necessidades, a ampliação da infraestrutura, profissionais qualificados e bem pagos, insumos adequados, produção de conhecimento e de tecnologias. Tudo isso requer mais investimento publico.

Em nome da governabilidade, os gestores repartem entre os partidos aliados os diversos setores da administração pública e, assim, a saúde se torna refém do clientelismo nos cargos de confiança, negligenciando o mérito, o profissionalismo, a competência técnica e a qualidade dos condutores da política de saúde.

O SUS representa muito para a populaçáo brasileira, e todas as evidências da ampliação do acesso observada nas três ultimas décadas devem ser creditadas à sua existência. Antes dele, menos de $10 \%$ da população usou serviços de saúde nos quinze dias anteriores à data em que foram entrevistadas. Atualmente, mais de 15\% teve acesso a esses serviços. A grande maioria da população atendida pelo SUS avalia seus serviços como 'muito bons'. Para ilustrar a ampliação efetiva de acesso propiciada pelo sistema, em 1998 as pessoas que dispunham de um plano privado de saúde tinham 200\% mais chances de usar um serviço de saúde em relação àquelas que não tinham tal benefício. Hoje, esta relação está abaixo dos 70\%. 
Entretanto, 24 anos após sua criação, o SUS ainda não conseguiu reverter as profundas desigualdades no acesso das pessoas aos serviços de saúde. Entre os mais pobres, mais de $20 \%$ não tiveram oportunidade de ir a uma consulta odontológica, fato que não ocorre entre as pessoas de renda mais elevada.

Em relaçáo à qualidade, a persistente presença da alta mortalidade materna testemunha a frágil qualidade da atenção oferecida, na maioria das vezes fragmentada e sem a retaguarda do apoio diagnóstico e terapêutico.

Nesse sentido é preciso insistir que o aumento no acesso não significa acessibilidade universal e, tampouco, dignidade. Se persistirem as análises ufanistas que desprezam a leitura da realidade da assistência à saúde no Brasil, não serão criadas as bases críticas nem as alternativas tecnológicas com vistas à mudança das formas de acesso, dos modelos de atenção e da qualidade do cuidado.

Estas mudanças, quando relacionadas ao modelo de atençáo, precisam considerar a complexidade da saúde e a atenção primária como eixo coordenador do processo do cuidado. Dito dessa forma, tudo parece simples, não fosse a cultura hegemônica que sempre localizou o hospital no centro da atenção à saúde, ocasionando a persistente dificuldade de compreender o sentido real da atenção primária. Este número da revista Saúde em Debate é mais uma contribuiçáo do CEBES para o entendimento da importância e do caráter da atenção primária. 